\title{
Smittsomme sykdommer blant pasienter ved Helsesenter for papirløse migranter i Oslo
}

KORT RAPPORT

RAGNHILD HELEN AUSTAD

Universitetet i Oslo

Ragnhild Helen Austad er medisinstudent.

Forfatteren har fylt ut ICMJE-skjemaet og oppgir ingen interessekonflikter.

\section{ELISABETH SANDBAKKEN}

E-post: elisabeth.sandbakken@studmed.uio.no

Universitetet i Oslo

Elisabeth Sandbakken er medisinstudent.

Forfatteren har fylt ut ICMJE-skjemaet og oppgir ingen interessekonflikter.

\section{HANNA SANDRIB}

Universitetet i Oslo

Hanna Sandrib er medisinstudent.

Forfatteren har fylt ut ICMJE-skjemaet og oppgir ingen interessekonflikter.

\section{PREBEN AAVITSLAND}

Folkehelseinstituttet

Preben Aavitsland er overlege ved Folkehelseinstituttet og kommuneoverlege i Arendal og Froland. Forfatteren har fylt ut ICMJE-skjemaet og oppgir ingen interessekonflikter.

\section{JOHAN N. BRUUN}

Institutt for klinisk medisin

Universitetet i Oslo

og

Oslo universitetssykehus, Ullevål

Johan N. Bruun er professor emeritus og frivillig ved Helsesenteret for papirløse migranter.

Forfatteren har fylt ut ICMJE-skjemaet og oppgir ingen interessekonflikter.

\section{FRODE EICK}

Kirkens Bymisjon

Frode Eick er sykepleier, M.phil. i International Community Health, og tidligere virksomhetsleder ved Helsesenteret for papirløse migranter.

Forfatteren har fylt ut ICMJE-skjemaet og oppgir ingen interessekonflikter. 


\section{BAKGRUNN}

Papirløse migranter faller trolig utenfor offentlige smittevernordninger. Hensikten med artikkelen var å beskrive utbredelsen av uoppdagete allmennfarlige smittsomme sykdommer blant pasientene ved Helsesenteret for papirløse migranter i Oslo.

\section{MATERIALE OG METODE}

Vi gjennomgikk journalene til alle som oppsøkte helsesenteret første gang i 2016 og hadde legekonsultasjon i 2016 eller 2017 med henblikk på alder, kjønn, oppholdstid i Norge, landkategori og infeksjonsprøvesvar i perioden 1.1.2016-31.12.2017.

\section{RESULTATER}

Det var fire nye tilfeller av hepatitt B blant 139 testede. Fire av 38 testede hadde klamydiainfeksjon. Det var ingen nye tilfeller av aktiv lungetuberkulose, syfilis, hivinfeksjon eller hepatitt C.

\section{FORTOLKNING}

Det var færre tilfeller av allmennfarlige smittsomme sykdommer enn det som kunne forventes ut fra hvilke land pasientene kom fra.

Allmennfarlige smittsomme sykdommer er infeksjonssykdommer som er særlig smittsomme, kan opptre hyppig og ha høy dødelighet eller gi alvorlige eller varige skader (1). For å bekjempe disse må utsatte grupper få informasjon og enkel tilgang til å teste seg. Papirløse migranter eller personer som befinner seg i landet uten oppholdstillatelse, er en spesielt utsatt gruppe. De har svært begrenset tilgang til offentlige helsetjenester, har ikke rett til fastlege og er derfor vanskelig å nå gjennom ordinære smittevernrutiner som krever inkludering i det norske helsesystemet (2). Mange av dem kommer fra land med høy forekomst av enkelte infeksjonssykdommer, men vi vet svært lite om utbredelsen av disse i denne gruppen.

I denne studien ønsket vi å se på utbredelsen av uoppdagete allmennfarlige smittsomme sykdommer blant pasientene ved Helsesenteret for papirløse migranter i Oslo, et gratis lavterskeltilbud drevet av Kirkens Bymisjon og Røde Kors.

\section{Materiale og metode}

Vi inkluderte alle pasienter som hadde første kontakt med Helsesenteret i 2016 og minst én registrert legekonsultasjon i 2016 eller 2017, totalt 388. Journalene deres ble gjennomgått i januar-februar 2018.

Helsesenteret tilbyr alle test for hivinfeksjon, hepatitt B og C og tuberkulose ved førstegangskonsultasjon. I tillegg tester man for disse og andre infeksjonssykdommer ved indikasjon. Helsesenteret bruker hurtigtest for hiv og syfilis og sender øvrige prøver til Oslo universitetssykehus. Pasienter som ønsker tuberkulosetest, henvises til Diagnosestasjonen ved Ullevål sykehus.

Vi noterte alder, kjønn, landkategori, selvrapportert oppholdstid i Norge samt prøveresultater for 2016 og 2017. Vi konsentrerte oss om lungetuberkulose, hepatitt B, hepatitt C, hiv, klamydia og syfilis. Landkategoriene baserte vi på Folkehelseinstituttets 
lister over land med særlig høy og høy forekomst av tuberkulose (3) og høy forekomst av hiv, hepatitt B, hepatitt C og syfilis (4).

Deskriptive analyser ble utført i Microsoft Excel 2016. Prosjektet er godkjent av Regional komité for medisinsk og helsefaglig forskningsetikk Sør-Øst (ref.nr. 2017/1851).

\section{Resultater}

388 pasienter ble inkludert, 186 menn og 202 kvinner. 216 var i alderen $15-35$ år, 161 var over 35 år, 10 var i aldersgruppen o-14 år og 1 pasient hadde ukjent alder. Oppholdstid i Norge var o-21 år (median 1 år, gjennomsnitt 2,5 år). 354 ( $91 \%$ ) kom fra land med særlig høy eller høy forekomst av minst én av sykdommene (tabell 1). Nesten halvparten (188) ble unders $ø$ kt for minst én av infeksjonene, og 15 av dem fikk påvist en infeksjon (tabell 2). Det var ingen nye tilfeller av aktiv lungetuberkulose, syfilis, hivinfeksjon eller hepatitt C, men to pasienter fikk påvist latent tuberkulose. Fire av 38 testede hadde klamydiainfeksjon. Det var fire nye tilfeller av hepatitt B (HbsAg-positive, sannsynlig kronisk bærerskap) blant 139 testede. Blant de med påvist infeksjon visste seks pasienter om sin hepatitt B-status og én om sin hepatitt C-status fra tidligere.

\section{Tabell 1}

Fordeling av 388 nye pasienter ved Helsesenteret for papirløse migranter i 2016, etter forekomst av visse infeksjonssykdommer i deres opprinnelsesland. Antall pasienter (prosent av totalt utvalg).

\begin{tabular}{|lrrrrr|}
\hline Forekomst & Tuberkulose & Hiv & Hepatitt B & Hepatitt C & Syfilis \\
\hline Særlig høy & $184(47 \%)$ & - & - & - & - \\
\hline Høy & $142(37 \%)$ & $149(38 \%)$ & $353(91 \%)$ & $214(55 \%)$ & $218(56 \%)$ \\
\hline Lav & $57(15 \%)$ & $236(61 \%)$ & $31(8 \%)$ & $170(44 \%)$ & $167(43 \%)$ \\
\hline Ukjent & $5(1 \%)$ & $3(1 \%)$ & $4(1 \%)$ & $4(1 \%)$ & $3(1 \%)$ \\
\hline
\end{tabular}

\section{Tabell 2}

Antall pasienter med påvist infeksjon (antall som ble undersøkt') i perioden 2016-17, blant pasienter som var nye ved Helsesenteret for papirløse migranter i 2016.

\begin{tabular}{|c|c|c|c|c|c|c|c|}
\hline \multirow{2}{*}{\multicolumn{2}{|c|}{ Utvalg }} & \multicolumn{4}{|c|}{ Klamydia Syfilis Hepatitt Hepatitt } & \multicolumn{2}{|c|}{ Hiv Lunge-tuberkulose } \\
\hline & & \multicolumn{4}{|c|}{$\begin{array}{llll}2 & \text { B } & \text { C }\end{array}$} & \multicolumn{2}{|c|}{ 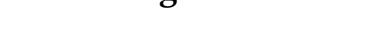 } \\
\hline Totalt $(\mathrm{N}=388)$ & & $4^{2}(38)$ & $\begin{array}{r}0^{3} \\
(98)\end{array}$ & $\begin{array}{r}10^{4} \\
(137)\end{array}$ & $1^{5}(121)$ & $\begin{array}{r}0^{6} \\
(159)\end{array}$ & $0^{7}(36)$ \\
\hline \multirow[t]{4}{*}{$\begin{array}{l}\text { Etter } \\
\text { forekomstgruppe }\end{array}$} & $\begin{array}{l}\text { Særlig } \\
\text { høy }\end{array}$ & - & - & - & - & - & $0(23)$ \\
\hline & Нøу & - & $\begin{array}{r}0 \\
(58) \\
\end{array}$ & $\begin{array}{r}9 \\
(129) \\
\end{array}$ & $1(74)$ & $\begin{array}{r}0 \\
(73) \\
\end{array}$ & $0(7)$ \\
\hline & Lav & - & $\begin{array}{r}0 \\
(40) \\
\end{array}$ & $1(7)$ & $0(46)$ & $\begin{array}{r}0 \\
(86) \\
\end{array}$ & $0(5)$ \\
\hline & Ukjent & - & 0 & $0(1)$ & $0(1)$ & $\begin{array}{r}0 \\
(0)\end{array}$ & $0(1)$ \\
\hline
\end{tabular}

${ }^{1}$ Hos én pasient lot innsendt prøve seg ikke analysere for hepatitt B og C, denne er ekskludert fra tabellen

${ }^{2}$ DNA-PCR-påvisning. Folkehelseinstituttet har ingen oversikt over land med høy forekomst av klamydia

${ }^{3}$ Mer spesifikk test enn screeningtest

${ }^{4}$ Testing for HBsAg (virusets overflateprotein) 
${ }^{5}$ HCV-RNA-test

${ }^{6}$ Spesifikk Hiv-antigentest

${ }^{7}$ Dyrkningsprøve av ekspektorat

\section{Diskusjon}

Vi vet at papirløse migranter i Norge lever ustabile liv preget av fattigdom og mangel på fast bolig $(5,6)$, og at de har liten tilgang til helsetjenester. Fordi mange av pasientene kommer fra land med høy forekomst av infeksjonssykdommer, hadde vi forventet å finne flere tilfeller av smitteførende infeksjonssykdommer, selv om under halvparten av pasientene ble testet.

Det kan være flere årsaker til den lave forekomsten. Helsesenteret opplever å ha stor tillit i brukergruppen, og vi har ikke grunn til å tro at pasienter med infeksjonssykdommer holder seg unna senteret. Én grunn kan være at mange av pasientene er tidligere asylsøkere. Disse har sannsynligvis gjennomgått testing ved ankomst og blitt behandlet. En annen forklaring kan være den såkalte «healthy migrant effect» (7), som postulerer at det er de friskeste som migrerer og at de derfor har bedre helsetilstand enn resten av populasjonen de kommer fra. Forskning viser imidlertid at effekten avtar med tiden og at den ikke gjelder for alle (8). En tredje mulig forklaring kan være at papirløse migranter har begrenset kontakt med det øvrige samfunnet på grunn av frykt for å bli oppdaget. Da blir de også i mindre grad utsatt for nye infeksjoner (9).

Selv om vi ikke har informasjon til å konkludere om dette, har studien gitt ny kunnskap om allmennfarlige smittsomme sykdommer hos en vanskelig tilgjengelig gruppe. Siden papirløse migranter mangler identifikasjonsnummer og dermed ikke kan gjenfinnes i offentlige registre, er denne studien det nærmeste vi kommer et bilde av byrden av allmennfarlige smittsomme sykdommer blant papirløse migranter i Oslo.

Svakheten ved studien er at funnene er usikre og vanskelig generaliserbare. Resultatene er basert på relativt små tall og journalinformasjon som ikke er skrevet med det formål å bli brukt i studier. Et generelt problem med forskning på denne gruppen er at vi ikke kjenner populasjonens størrelse eller demografi. Dermed kan vi heller ikke bedømme om utvalget i vår studie er representativt for papirløse migranter generelt.

Smittevernarbeid er et viktig tiltak for folkehelsen, og det er avgjørende at dette arbeidet skjer innenfor strukturerte rammer, også for papirløse migranter. Det bør vurderes om det er riktig at tilgangen til smittevern knyttet til allmennfarlige smittsomme sykdommer blant papirløse migranter i hovedsak skal ligge hos private ideelle tiltak, som i dag bare finnes i Oslo og Bergen (10).

\section{Konklusjon}

Blant pasienter som var nye ved Helsesenteret for papirløse migranter i Oslo i 2016, var det uvanlig med nyoppdaget allmennfarlig smittsom sykdom. Forekomsten av infeksjonssykdommer var lavere enn det som kunne forventes ut fra forekomsten i de landene som pasientene kommer fra. Det trengs gode rutiner for smittevern og gode helsetjenester for dem som får påvist infeksjon. Videre trengs mer forskning om forekomsten av infeksjoner blant papirløse migranter og om ivaretakelse av disse pasientene.

\section{HOVEDFUNN}

$91 \%$ av de 388 pasientene i utvalget kom fra land med høy forekomst av minst én av infeksjonssykdommene vi så på i denne studien. 
$48 \%$ ble testet for minst én av disse.

Fire pasienter fikk påvist klamydia, og fire hadde nyoppdaget hepatitt B.

Vi fant ingen nye tilfeller av hepatitt C, hivinfeksjon, syfilis eller aktiv lungetuberkulose.

\section{LITTERATUR:}

1. LOV-1994-08-05-55. Lov om vern mot smittsomme sykdommer (smittevernloven). https://lovdata.no/dokument/NL/lov/1994-08-05-55 Lest 21.2.2020.

2. FOR-2011-12-16-1255. Forskrift om rett til helse- og omsorgstjenester til personer uten fast opphold i riket. https://lovdata.no/dokument/SF/forskrift/2011-12-16-1255 Lest 13.2.2020.

3. Folkehelseinstituttet. Land med høy og særlig høy forekomst av tuberkulose. https://www.fhi.no/sv/smittsomme-sykdommer/tuberkulose/land-med-hoy-forekomst-av-tuberkulo/ Lest 13.2.2020.

4. Folkehelseinstituttet. Oversikt over land med høy forekomst av hivinfeksjon, hepatitt B, hepatitt C og syfilis 2016.

https://www.fhi.no/globalassets/dokumenterfiler/veiledere/landliste-asylsokere_151216.pdf Lest 13.2.2020.

5. Årsmelding. 2017. Helsesenteret for papirløse migranter. Oslo: Kirkens Bymisjon, 2018. https://kirkensbymisjon.no/content/uploads/2018/o6/\%C3\%85rsmelding-Helsesenteret-2017.pdf Lest 13.2.2020.

6. Myhrvold T, Småstuen MC. The mental healthcare needs of undocumented migrants: an exploratory analysis of psychological distress and living conditions among undocumented migrants in Norway. J Clin Nurs 2017; 26: 825-39. [PubMed][CrossRef]

7. Fennelly K. The "healthy migrant" effect. Minn Med 2007; 90: 51-3. [PubMed]

8. Rubalcava LN, Teruel GM, Thomas D et al. The healthy migrant effect: new findings from the Mexican Family Life Survey. Am J Public Health 2008; 98: 78-84. [PubMed][CrossRef]

9. Eick F, Cassidy RE. Hivtester papirløse migranter. Sykepleien 2013; 3: 60-3.

10. Årsmelding 2018. Helsesenteret for papirløse migranter. Bergen: Røde kors, Kirkens bymisjon, 2018. https://www.rodekors.no/contentassets/bfe445c19d524c21bb13676e16632331/arsmelding-2018-helsesent eret.pdf Lest 21.2.2020.

Publisert: 16. mars 2020. Tidsskr Nor Legeforen. DOI: 10.4045/tidsskr.19.0074

Mottatt 23.1.2019, første revisjon innsendt 11.10.2019, godkjent 13.2.2020.

(C) Tidsskrift for Den norske legeforening 2020. Lastet ned fra tidsskriftet.no 